\title{
Corporate social responsibility of Colombian tobacco industry: Is it a strategy? ${ }^{\text {1 }}$
}

\author{
Responsabilidad social empresarial de la industria de \\ tabacalera en Colombia: ¿Es una estrategia? \\ Recibido: 09 de abril de 2014 - Revisado: 21 de julio de 2015 - Aceptado: 14 de septiembre de 2015
}

Diana Niño Muñoz ${ }^{2}$

\begin{abstract}
This research focuses on Corporate Social Responsibility (CSR) by tobacco companies in order to answer whether these companies used CSR initiatives in Colombia as a strategy to enhance the corporate image and counter their bad reputation, as part of its strategy to prevent further advances in regulation. I used a qualitative data analysis to process the documents available on its official internet pages and major national media between 2008 and 2011. The most important conclusion is that the tobacco companies appear as a strategic partner in efforts for development of the country, with two possible objectives: to improve their image and gain influence in political processes. It is necessary to consider these strategies especially in light of the scope of the ban to sponsorship and promotion that the industry has.
\end{abstract}

\section{Keywords}

Corporate Social Repomsibility, CSR, tobacco control, monittormg.

\section{Resumen}

Esta investigación se centra en la Responsabilidad Social Corporativa (RSC) de las compañías tabacaleras con el objetivo de responder si estas compañías usaron las iniciativas de RSC en Colombia como una estrategia para mejorar la imagen corporativa y contrarrestar su mala reputación, como parte de su estrategia para evitar mayores avances en la regulación. Utilicé un análisis de datos cualitativos para procesar los documentos disponibles en sus páginas de internet oficiales y en los principales medios de comunicación nacionales entre el 2008 y el 2011. La conclusión más importante es que las compañías tabacaleras aparecen como un socio estratégico dentro de los esfuerzos de desarrollo del país, con dos posibles objetivos: mejorar su imagen y ganar influencia en procesos políticos. Se hace necesario considerar de manera especial estas estrategias a la luz del alcance de la prohibición al patrocinio y promoción que tiene la industria.

\section{Palabras clave}

Responsabilidad Social Corporativa, RSC, Control de tabaco, Monitoreo.
1 Research paper that is a result of the project "Making the Colombian anti-tobacco law work" at Escuela de Economía of Universidad Sergio Arboleda, Bogotá, Colombia. I was funded by Bloomberg initiave suported by Unión Internacional contra la Tuberculosis y Enfermedades Respiratorias and Organización Panamericana de la Salud. (Opinions, mistakes, omissions are the exclusive author's responsibility). The author thanks Prabhat Jha and Blanca Llorente for their comments and support in the process of building up this paper.

${ }^{2}$ Magister in Interdisplinary Studies on Development from Universidad de Los Andes, Bogotá, Colombia and Specialist in Organizations, Social Responsibility and Development at this University. Ba.Sc. Economics and B.PH. Philosophy at Universidad Sergio Arboleda. Researcher and professor at Escuela de Economía of Universidad Sergio Arboleda, Bogotá, Colombia.

Email: diana.nino@usa.edu.co

For citation use: Niño-Muñoz, D (2015). Corporate social responsibility of Colombian tobacco industry: Is it a strategy? Revista Civilizar Ciencias Sociales y Humanas, 15(29), 113-134. 


\section{Introduction}

In Colombia there are two major players in the tobacco industry: Philip Morris International (PMI) and British American Tobacco (BAT). In 2005 PMI acquired Coltabaco and in 2011 BAT purchased Protabaco, both tobacco manufacturing companies in the country. Before these firms entered the Colombian industry, they already used Corporate Social Responsibility (CSR) as a tool to build a positive image and counteract the bad reputation coming from the devastating health consequences deriving from consuming their products (Fooks et al., 2011; Hirschhorn, 2004). More recently, public documentation from Coltabaco also recognizes not only its intentional use of this strategy to discourage tobacco control efforts, but also to report success in its efforts (Patino, 2013).

Based on these authors, this paper presents the following research question: Are those transnational firms using CSR initiatives in Colombia as a strategy to prevent stronger regulation? To answer it, this paper used a Qualitative Data Analysis to process a monitoring of the documents available in their official web pages and in local main media between 2008 and 2011. The most important conclusion is that the tobacco companies appear as a key partner in the country's development efforts with two possible objectives: to improve image and to gain influence on political processes. The procedure and results of this research may provide an outline for a mechanism to monitor those practices regularly and to contribute to inform valuable tobacco control strategies for both the government and the civil society. Hopefully, this analysis will also provide more elements to understand the challenges of regulation to counteract their strategies.

The paper is structured in six sections, including this introduction, as follows: section two presents some of the most salient approaches to CSR. Section three reviews the background about the CSR of the Tobacco Industry. The next section describes the qualitative methodology applied to organize and analyze the information. Section five shows the main results obtained after applying the different codes defined in the methodology to classify the information. To introduce the abundant material in a tractable way, results are presented in three stages. First, tobacco industry's activities reported in the official media between 2008 and 2011 are described in terms of a timeline, linking them to the normative developments that allowed the inception of the Tobacco Control Act in Colombia (Ley 1335 de 2009). The latter is the main reason to choose that period, which was the most active in terms of discussion and adoption of regulatory changes fostered by the implementation of the Framework Convention on Tobacco Control (FCTC). Second, CSR of the two major tobacco companies in Colombia are exposed according to the evidence found in the official websites between 2008 and 2011 with a review in 2015. The results section ends with an exposition of other salient findings. Section six discusses the previous results considering some of the key theoretical elements mentioned in section two. Finally, the last section offers conclusions and recommendations.

\section{Corporate Social Responsibility approaches}

Porter and Kramer (2006) are pioneers proposing CSR as a business strategy to acquire competitive advantage. Strategy is different from activities or practices, because these are a part of the strategy. In this sense, Lindgreen, Córdoba, Maon and Mendoza (2010,pp. 230-231) consider that organizations' strategies must "fit their social context and find meaningful ways to work with local communities by combining various elements of CSR practices". Then, strategic CSR must go beyond the best practices and shift from a fragmented posture to an integrated approach (Porter \& Kramer, 2006).

Nevertheless, CSR is not a univocal concept, and it has not been adopted in the 
same way by the firms. Thus, it is convenient to understand some of these approaches before undertaking the task of analyzing CSR in tobacco companies in Colombia. The literature on this topic identifies several classifications about CSR theories (Argandoña, 2007a, 2007b; Carroll, 1999; Garriga \& Melé, 2004, 2013; Melé, 2004). For the purposes of this paper the classification suggested by Garriga and Melé (2004) is appropriate because it has a wide scope that presents a rather complete landscape of the debates and consensus surrounding the types of CSR and the strategies that the firms should adopt or actually use. An analysis of this classification was developed in a previous study (Niño-Muñoz, 2012), where the reader can deepen the explanation of the categories presented in this paper. Among all the categories identified by Garriga and Melé (2004), four of them seem quite relevant for the type of analysis intended here: maximizing the shareholder value, cause-related marketing, corporate constitutionalism, and the common good approach.

The main exponent of the first category -maximizing the shareholder value- is Friedman (septembre $13^{\text {th }}, 1970$ ) who stated that "there is one and only one social responsibility of business to use its resources and engage in activities designed to increase its profits so long as it stays within the rules of the game". Although this posture implies limitations, this is not the place to get into that discussion. Suffice to say that the objective of this paper is not to stigmatize economic profit. It acknowledges the fact that profit allows the functioning, maintenance and expansion of the firms (Debeljuh, 2009). In fact, safeguarding the optimum use of the resources to obtain benefit is a central responsibility of any firm. But it does not follow that this should be the only or even the main responsibility. The firm should go "beyond the mere economic contract with society" (Paladino \& Willi, 2004, p. 91) and should remember that wealth accumulation is good as a means to a higher end (Aristóteles, 2013, original in 1475).
The approach known as cause-related marketing conceives CSR as strategies to improve the firm's image, increasing sales and economic benefit. This should not be interpreted as a criticism against the firms' efforts to communicate the positive social effects emerging from their activities. Stakeholders -including shareholders, but also other groups concerned with the firm's sphere of influencehave the right to be informed (Hoyos-Vásquez $\&$ Solarte, 2007) and with this communication companies have the possibility to align corporate behavior with stakeholder expectations (Dawkins, 2005). Even more, "spreading the information on CSR activities performed by the firm might motivate other firms to adhere to that same vision and effort" (Pezoa, 2004, p. 280). Likewise, communication about these practices promotes among consumers the firm's reputation, its credibility and honesty and increases their loyalty to the firm's products (Park, Lee, \& Kim, 2014). The problem with this approach emerges when the content of the communication is not a consequence of the firm's actions (Pezoa, 2004). When beneficiaries are not related with the company's core business, it generates suspicion with regard to the sincerity of the firm (Yoon, Gürhan-Canli, \& Schwarz, 2006). In consequence, "activities, which typically exploit cause-related marketing, are classical musical concerts, art exhibitions, golf tournaments or literacy campaigns" (Garriga \& Melé, 2004, p.55).

Continuing with the suggested category review, corporate constitutionalism understands the firm as a social institution with a certain amount of power over the society, power that should be used in a responsible manner (Garriga $\&$ Melé, 2004). Likewise, this approach views the firm as a political organization "because it contributes to the shaping of society" (Paladino \& Willi, 2004, p. 111). In a continuously globalizing world, where transnational companies control an increasing piece of the world economy, their actions have a bigger impact. Thus, the political dimension of these firms becomes 
larger and even more real in terms of their potential to act and improve the quality of their own milieu. Davis (1960), a pioneer in this subject, states that one of the essential laws in the management of the firm's social power is the iron law of responsibility. According to this law, "in the long run those who do not use power in a manner which society considers responsible will tend to lose it because other groups eventually will step in to assume those responsibilities" (Davis, 1960, p. 63).

Last, this analysis considers relevant the common good approach, which stands among the ethical theories of CSR. This approach sees the organizations as intermediate social institutions between the individual and society, and in turn, the organizations have a responsibility in this relationship: to contribute to common good (Aguilar, 2011; Melé, 2004). The common good should be understood as "the set of all conditions of social life which allows groups and every member of these groups to reach their perfection in a fuller and easier way" (Catecismo Iglesia Católica, CIC, 1992, p.427). This view assumes that CSR as a set of "policies and programmes generated by the firms and enforced voluntarily, in order to face their responsibilities to their stakeholders and society in general" (Argandoña, 2007c, p. 1), and with the purpose of improving their milieu, and contributing to common good.

In sum, this previous analysis allows highlighting conditions of a complete CSR behavior. A responsible firm should get profit to secure functioning, maintenance and expansion of the company (Debeljuh, 2009); it should communicate sincerely companies' activities to align corporate behavior with stakeholder expectations (Dawkins, 2005) and to motivate other firms to follow the same path (Pezoa, 2004, p. 280). Although, a responsible firm understands its power over society and contributes to shape it (Paladino \& Willi, 2004, p. 111) and to promote the common good (Melé, 2004).

\section{Background about the CSR of the tobacco industry}

In the last years, CSR has become an important facet of any company; especially in those with bad reputation (e.g., tobacco firms) which are interested in improving their negative image through CSR activities (Yoon et al., 2006). It is expected that CSR creates trust in the company and it will bring an improved perception of the firm (Park et al., 2014). However, it depends on the perceived sincerity of the company's motives to achieve positive or negative effects (Yoon et al., 2006).

Sincerity in CSR initiatives of Tobacco companies is questioned, because on one side cigarettes cause harm and death, and, on the other, they make marketing efforts to target young people (Chapman, 2004; Palazzo \& Richter, 2005; Yoon et al., 2006) and women (Ho, Shi, Ma, \& Novotny, 2007). Thus, CSR initiatives constitute a "strategic goal to distract attention from their controversial activities, lessen the negative consequences of stigmatization and neutralize the impact of litigation proceedings" (Grougiou, Dedoulis, \& Leventis, 2015 , p. 295). In fact, studies found that tobacco companies have used CSR in UK (Fooks et al., 2011) and in USA (Hirschhorn, 2004) as a tool to build a positive image and counteract the bad reputation coming from the devastating health consequences deriving from consuming their products.

CSR of tobacco companies has also been questioned because academics have asked for two requirements of CSR concept: i) to contribute to the well-being of society; and ii) to abolish Corporate Social Irresponsibility (CSI), such as cheating customers (Lin-Hi \& Müller, 2013). Avoiding CSI is a central precondition to be socially responsible (Lin-Hi \& Müller, 2013). From this perspective, in a historical approach, Palazzo and Richter (2005) found that tobacco companies have presented the following behavior: massive lobbying 
and misinformation campaigns publicly; also sponsored researches to put on doubt scientific evidence about the addictive character of nicotine and the association between cigarettes and lung cancer; and a political hidden agenda to get lower tobacco taxes.

\section{Methodology}

A process of data collection and then a qualitative data analysis were implemented to answer the research question. Two forms of data collection were used. First, a search of CSR initiatives that tobacco companies reported it was done in 2011, July 8 using the official documents available in www.pmi.com, www.batcolombia. com, www.protabaco.com (Coltabaco did not have web page, because it shared it with PMI). 14 CSR programmes self-reported by BAT, Protabaco and PMI were identified (Annex 1). This review was rerun on 2015, September 30 to identify any relevant change since the original search date. In this new report, www.protabaco.com disappears because BAT acquired Protabaco and now they share the same web page.

Second, a monitoring of news in the country's most important mass media was performed, considering the period between 2008 and 2011. The selected period of time looked for monitoring possible changes in the firms' strategies before and after the approval of the tobacco control act of 2009 in Colombia (Ley 1335 de 2009). This period was the most active in terms of discussion and adoption of regulatory changes fostered by the implementation of the FCTC. In addition, monitoring media were identified as a useful methodology because stakeholders expect to know about CSR activities through firms' communications and unbiased media sources (Dawkins, 2005). The following media databases were searched to identify tobacco industry's activities: El Tiempo; El Espectador; CityTV; Portafolio, Semana, Caracol; $R C N$. In addition, other publications in Colombia were identified using Google News. Nevertheless, most of the search was done in the Internet archives of El Tiempo and El Espectador, because they are the most important mass media in Colombia with national coverage and larger records in internet. This collection method is similar to the exposed by Atusingwize, Lewis and Langley (2015). In sum, 824 news reports were collected.

The search terms of news monitoring were developed in relation to the tobacco industry's activities. The following key terms were used to perform the searches in the data bases of media: Tobacco, cigarette, Phillip Morris, British American Tobacco, Protabaco and Coltabaco. During the process a number of obstacles limited the scope of the search. First, the years with information available in the databases of $E l$ Tiempo and El Espectador went as far back as 2008. The TV channels CityTv and Caracol (both with news shows) provided information only since 2009. In 2010 and 2011 the information available came from a wider range of sources, such as RCN (TV news show), La República and Portafolio (newspapers), Semana (magazine), among others. A second limitation was the lack of standardized terms in the search engines (unlike more specialized sources), because the search results obtained with the selected key terms produced many irrelevant results, so the manual selection involved considerable time.

After data collection, a Qualitative Data Analysis was used inspired by Cisterna-Cabrera (2005) and Ulin, Robinson, and Tolley (2006). First, deductive categories were constructed to allow an organized compilation of news and documents. In the case of CSR initiatives that tobacco companies reported, they were classified in four topics: Health; Agricultural; Environmental; Social (Annex 1). For monitoring of news, I used two organized parameters: i) the research question and ii) the objective of looking possible changes in the firms' strategies before and after the approval of Law 1335 in Colombia. Initially five topics have been included for news monitoring. One was related with CSR and community activities of the tobacco com- 
panies in Colombia. The other four were chosen considering key topics in the FCTC, which are involved in the Colombian Law 1335: Smokefree areas; sales of cigarettes individually; promotion, advertising and sponsorship; prices, taxes and smuggling. A monitoring news' matrix was built to distinguish each category.

Second, I identify other typologies that emerge from data. In the case of CSR initiatives, the results were presented in five final categories: cultural events; youth campaigns; community campaigns; environmental programmes and regulation. In the case of news monitoring, besides those already exposed, I included seven new categories related with general tobacco issues and CSR programmes: Colombian Law 1335 of 2009; tobacco industry; international context; health; campaigns (smoking cessation and education for prevention); agriculture; and other information. It was necessary to establish limits of each topic and to check the first monitoring news' matrix.

Third, a data reduction was done to synthesize the information and to identify important concepts and essential relationships. The information was analyzed with three approaches: i) tobacco industry's activities were described in terms of a timeline; ii) CSR initiatives and other important findings were exposed with the mentioned categories; and iii) classification of CSR theories presented in this paper was used to deduce CSR strategies of the firms: maximizing the shareholder value, causerelated marketing, corporate constitutionalism, and the common good approach. Finally, I achieved results and conclusions.

\section{Results.}

\section{Tobacco industry activities along a timeline}

In the international scenario, at the beginning of 2008 many countries -such as Germany, France, Portugal (Leyes confinan a fumadores en sus casas, 03 de enero de 2008) and Turkey (EFE, 2008)- started to develop tobacco control laws following the example of successful experiences in other countries like England, Canada and Uruguay. At the same time, the World Health Organization (WHO) published in its report on the global tobacco pandemic, that "tobacco consumption will increase in poor countries as a result of the tobacco industry's strategy to attract young people and women in these nations, where now live $80 \%$ of smokers" (Las tabacaleras buscan más fumadores en países pobres, 08 de febrero de 2008). In the meantime, in Colombia the National Cancer Institute (INC) released their estimates on the impact of tobacco consumption in Colombia, which caused 20,000 annual deaths and a financial burden of 2,2 billion pesos (about U\$ 1`118.454, $5^{1}$ ) (Las tabacaleras buscan más fumadores en países pobres, 08 de febrero de 2008). The results from the global youth tobacco survey (GYTS) showed that $29.8 \%$ of students from a sample of 50 schools in Bogotá between 6th and 9th grades, were smokers and $61.6 \%$ had tried cigarettes at least once (Tabaquismo en Niños, Lío Mayor, 2008). This scenario indicates that the worries about tobacco consumption as a public health problem were present in the media.

Despite these warnings of initiatives to reduce consumption such as the adoption in Colombia of the FCTC in 2006, the tobacco industry continued with expansion projects in the country. In December 2008 Coltabaco announced its intention to increase the cultivated area (Coltabaco impulsa el cultivo de 500 hectáreas de tabaco en la costa norte, 03 de diciembre de 2008). In 2009 it communicated its plans to invest more than US\$130 million during the following four years (Dominguez, 2009) and expand its export goals to Brazil, Mexico, Costa Rica, Guatemala, Dominican Republic and Europe (Coltabaco Exportará, por Primera vez, sus Productos a Brasil, 2009). Within this strategy, the company intended to promote tobacco production in areas affected by long- 
term violence, such as Montes de María (Las tabacaleras buscan más fumadores en países pobres, 08 de febrero de 2008) and in the states (departamentos) of Sucre and Bolívar (Contratos para fomentar cultivo de tabaco, 2009). The program included seeds supply, "free technical assistance, financial aids for peasants and sales contracts with fixed prices to secure stable cash flows and reduce uncertainty about expected crop revenues" (Coltabaco impulsa el cultivo de 500 hectáreas de tabaco en la costa norte, 03 de diciembre de 2008, traducción del autor). All these were also devised in an environmentalfriendly framework. With these investments, the company declared they expected to contribute to the generation from 25.000 (Dominguez, 2009) to 30000 (Quintero, 08 de junio de 2010) rural employments, and to the consolidation of the peace process through the support of agricultural activities for displaced families (La nueva cara de El Salado, 08 de julio de 2011). By this token, Coltabaco stated: "[we] hoped that Colombia would become a tobacco leaf export center for other subsidiaries of PMI" (El país sembrará más tabaco, 2009, traducción del autor). In the process, the company established cooperation bonds with institutions such as Quindio's Economic, Rural and Environmental Development Office (Cultivos de tabaco generarán más empleos en el Quindío, 19 de marzo de 2010), the US Agency for International Development (USAID), the International Organization for Migration (IOM), the National Commission for Reparation and Reconciliation (CNRR), Semana Foundation (Santos dice que en la Masacre de El Salado hubo omisión, 08 de julio de 2011) and Social Action (the main government program developing social policies), (La nueva cara de El Salado, 08 de julio de 2011).

Protabaco also promoted in the media their expansion programs, although only their brands Mustang and Premiere were produced with local tobacco leaf (Cantillo, 2011). At the beginning of 2008, Protabaco signed new export contracts with European countries (Protabaco firma nuevos contratos de exportación,
11 de marzo de 2008) and established a strategic alliance with Corpoica, Unisangil and Universidad Nacional de Colombia to develop five research projects approved and co-financed by the Ministry of Agriculture (Protabaco alista plan para mejorar cultivos, 19 de mayo de 2008). Similarly, in 2010 this tobacco company jointly with the Agriculture and Cattle Guarantee Fund supported small farmers' projects and helped them have access to special credit lines offered by Banco Agrario de Colombia (the government's bank to promote agriculture), (Mantienen oferta de crédito, 29 de mayo de 2010). During the rain emergencies in 2011 Protabaco, the Ministry of Agriculture and MAPFRE offered an insurance and subsidy program to secure crops and crop quality (Cantillo, 2011).

In the legislative field, Colombia has also advanced rapidly. On 2008, May 30, the Ministry of Health issued a regulation on smoke free areas, Resolution 1956, which banned smoking in closed public spaces (Prohíben fumar en recintos públicos, 31 de mayo de 2008). Although in an early stage the National Bar Association had sent a letter of complaint against this norm, later this organization changed its position and provided full support to one of the law draft on tobacco control (Ley antitabaco supera otro escollo en el senado, 19 de noviembre de 2008). The said letter stated the Association's concern, among other things, about not having been included in the discussion of a norm that, according to the Association, violated public freedoms of citizens and made owners of establishments responsible for the behavior of their clients (Piden revocar medidas contra los fumadores, 05 de julio de 2008).

Under these circumstances, early in 2008, three law proposals were presented to the Congress, all of them aiming at the regulation of the FCTC (En el Congreso de la Republica tres proyectos de ley sobre el tema, $27 \mathrm{de}$ mayo de 2008): The first law proposal, led by Senator Dilian Francisca Toro, "emphasizing 
the protection of minors from the exposure to smoke and from industry's advertising" and banning individual cigarette sales; the second one led by Senator José David Name focussing in smoke free areas (De Espejo, 07 de noviembre de 2008) as the last law proposal from Senator Zulema Jattin. Several aspects of the debate surrounding these proposals should be mentioned. First, the press exposed accusations about certain alterations to the two last proposals, asserting that "they [did not have] the exact content of the FCTC, which had already proven to be effective in the reduction of tobacco consumption." (En el Congreso de la Republica tres proyectos de ley sobre el tema, 27 de mayo de 2008; Hay micos de senadores en ratificación del convenio contra el tabaco Claudia Víctor, 12 de abril de 2009, traducción del autor) Second, regarding the measures to ban individual cigarette sales, the president of the Association of retailers, FENALCO, rejected the sanctions considered in the proposal, in view of the situation of small retailers. Other senators expressed concerns about the impact on the informal street sellers (Polémica por venta fácil de cigarillos, 05 de mayo de 2009). Third, a letter of the vice minister of agriculture was sent to the National Television Commission to keep cigarette advertising at night time (Rodríguez, 15 de junio de 2009). One final area of debate was the accusation by Senator Name about bribes worth $\$ 500$ million pesos as well as death threats pressing him to withdraw his proposal. He expressed his belief that these threats did not come from the tobacco industry (De Espejo, 07 de noviembre de 2008). However, months later in the midst of a Congress debate that resulted in the addition of two paragraphs which distorted the original text of his proposal (Dmoteroa, 22 de mayo de 2009), Name "denounced the industry's constant lobby and pressures to sink the proposals that attempted to pass legislation to reduce tobacco consumption" (Con "Micos" en Ley antitabaquismo buscan eliminar espacios libres de humo, 21 de mayo de 2009, traducción del autor). He added in another interview that "it [was] no coincidence [that]
22 law proposals on tobacco control had not prospered in Congress" (Rodríguez, 15 de junio de 2009). Bogotá's Health Authority supported these statements (Citytv, 29 de mayo de 2009), and even other senators accused the tobacco companies (Phillip Morris niega sobornos para tumbar Ley Antitabaco, 12 de junio de 2009). Regarding these accusations, PMI denied any involvement in bribery. With the development of the debates it came as a surprise the approval of Senator's Dilian Francisca Toro proposal in July, which became Law 1335 in 2009, the current tobacco control Act in Colombia.

Last, it is important to describe briefly the acquisition process of Protabaco by one of the largest and most powerful tobacco companies in the world. In July, 2009, PMI announced its intention to buy this Colombian company (Philip Morris compra a Protabaco por US $\$ 452$ millones, 10 de julio de 2009). However, after a long debate in June, 2010, the Superintendence of Industry and Commerce, SIC, the agency in charge of anti-trust regulation in Colombia, rejected the operation due to violation of market concentration restrictions (PMI already owned in 2005 the other tobacco manufacturing company in the country, Coltabaco), (No fue aprobada la compra de Protabaco por Phillip Morris, 13 de junio de 2010). The announcement was obviously unwelcomed and after several months, finally it was BAT which purchased Protabaco in May 2011 (British American Tabacco compra a Protabaco por US\$452 millones, 26 de mayo de 2011).

\section{CSR activities of tobacco companies}

Continuing with the analysis, now the CSR initiatives of the tobacco companies are described through established categories. The information comes from the websites of these firms and from information published on the press. See Annex 1 for a summary of the initiatives reported in the websites of the tobacco companies. 
The first category used to synthetized information is cultural events. The sponsorship of cultural events is particularly frequent for BAT through BAT Foundation. The Law 1335 bans the sponsorship when it "implies the direct or indirect promotion of tobacco products and its derivates". But the manager of BAT Foundation explained that "the Foundation has never sponsored the brands of the company nor has mentioned them" (BAT seguirá con salón de arte popular; Ley antitabaco no afectará su realización, 26 de julio de 2009, traducción del autor); therefore, they do not have intentions to stop this practice. "The Foundation [has sponsored] 28 popular festivals, 12 itinerant exhibitions with the First BAT Salon of Popular Art, 6 exhibitions with the second Salon, reaching up to 4 million visitors and 8.177 artists" (En pro del arte, 22 de abril de 2008, traducción del autor). The Third BAT Salon of Popular Art promoted the contest in the framework of the celebration of the two-hundred anniversary of Colombia's independence, with the participation of 1644 works from all over the country (British American Tobacco, BAT, 2010). In the same lines, Coltabaco (PMI) organized the contest for short films by young artists, Instinto Bogotá, and Protabaco has also sponsored regional festivals (Cabalgata, concierto, toros y silletas son las actividades programadas para la fiesta de Sogamoso, 15 de julio de 2010).

The following are programs classified in the second category, youth campaigns. Since 2008 BAT Colombia, in cooperation with Fenalco, started a campaign called Prevención de Fumadores en Menores de Edad (Smoking Prevention Among Minors) (Comprometida con la prevención del consumo de tabaco en menores de edad, 30 de agosto de 2008). Likewise, Coltabaco reinforced this campaign with a programme oriented to small retailers called $N o$ somos adivinos muéstranos tu cédula (We are not psychic, show us your ID) (Campaña contra el cigarrillo para menores de edad, 20 de octubre de 2008.). Later, in 2010, BAT Colombia, Fenalco, RCN Compromiso Social and Petrobras started the campaign Dígale si a su responsabilidad de decir no (Say yes to your responsibility of saying no) with the stated objective of increasing awareness of retail sellers, reaching 41.000 stores, supermarkets and gas stations across the country (No fue aprobada la compra de Protabaco por Phillip Morris, 13 de junio de 2010). Other two activities from Coltabaco mentioned in the media were, on the one hand, a program to promote student internships called Primer Paso (First step), offering university students working opportunities in the company (Coltabaco busca el mejor talento de las universidades en Colombia, 23 de noviembre de 2010). On the other hand, Coltabaco donated a soccer field, with changing rooms and stands with a beneficiary population of 500 children in Altos de Cazucá (a low income area in the outskirts of Bogotá), (En sus marcas, 16 de noviembre de 2011). Another campaign with similar features was Fanáticos Mustang (Mustang is one of the leading brands from Protabaco), which tried to encourage smokers to pick up cigarette butts and throw them in trash cans (Hernández, 13 de abril de 2011). Last, the media covered the contest to design a Mustang horse oriented to university students.

In the category community campaigns, it is worth mentioning two initiatives. One oriented toward the adaptation of former members of illegal armed forces and the other to support victims of natural catastrophes (mainly due to the heavy rainy seasons). Regarding the first groups, Coltabaco and other firms started three programmes: the first one, offered help to these people to become managers in 25 mini-markets (Artuz, 24 de noviembre de 2011); the second one is a programme to engage them in tobacco agriculture (Piden erradicar miedo de contratar desmovilizados, 05 de mayo de 2011), and the third is the initiative Ruta Ciudadana (Citizen path), which offered a tour around Medellin with recreational purposes and workshops about territory, identity, community life, among other topics (Mira, 31 de diciembre de 2011). Otherwise, to the victims of the floods, BAT Colombia jointly with the foundation Un techo para mi pais (A rooffor my country) organized a 
volunteer plan to build 12 housing units in four cities, an activity funded with the money and time provided by the firm's employees (Alianza de BAT Colombia con un techo para mi país, 03 de abril de 2010).

In the fourth category, environmental programmes, Coltabaco organized the campaign Green Print to encourage among the company's employees a reduction in the consumption of paper and printing materials (Ambientes laborales sanos, 24 de marzo de 2010). In 2010 Protabaco received a recognition for his environmental friendly activities (Premiaron a 58 empresas bogotanas por ser amigables con medio ambiente, 22 de diciembre de 2010) and Coltabaco was a candidate at the Portafolio Prizes in the Social Responsibility category. In 2011, BAT Colombia launched a project with Universidad Nacional to promote organic tobacco crops, without using artificial fertilizers and pesticides, with the purpose of positioning Colombia as a supplier with denomination-of-origin cigarettes (Cigarrillos con sello propio, 21 de junio de 2011).

The final category, regulation, appears in the review rerun on 2015, september 30 . PMI makes explicit in its web page its interest of making "advocacy to establish regulations around the world that help prevent tobacco consumption by minors" (Philip Morris Internacional, PMI, 2015a). Additionally PMI considers its responsibility to make its "views clear to those who have the potential to affect the laws, regulations, and policies that can influence [its] global business" (Philip Morris Internacional, PMI, 2015b, traducción del autor).

\section{Other results}

Other results that could be related with the tobacco industry's CSR were identified during the search process:

The Magazine "Bakanica" included an add promoting a contest to redesign the horse symbol which identifies a leading local brand
(Mustang). Bakanica is a magazine edited by a university with links to an international health care organization, and distributed free of charge in the main universities in Colombia. The contest's prize was the full payment of one semester's tuition.

The Federación Nacionalde Comerciantes (Fenalco) produced a brochure about the AntiTobacco Law and its restrictions. The material is not explicitly linked to any tobacco company, but BAT reports alliances with Fenalco. This brochure states that "the law does not restrict commercialization, production and distribution of cigarettes." This clearly misinforms the public because although Colombian legislation allows engaging in these activities, they are clearly subject to restriction.

Finally, it is important to stress the pattern observed in tobacco industry's CSR programmes, which always takes place in alliance with recognized institutions, mostly those dealing with problems in the agricultural sector. Many of these projects become symbolic programmes of public-private partnerships addressing problems related with the efforts to advance in the development process of the country. This kind of interventions in the agricultural sector is perceived as very important in the Colombian case, considering local concerns about illicit crops substitution and poverty in rural areas. Apparently, this is one of the image-building strategies used by the tobacco industry to justify the expansion of its tobacco production in Colombia.

\section{Discussion}

After understanding the Colombian context and the trends in CSR strategies of tobacco companies in the country, the next step is the analysis of these activities from the perspective of different approaches presented in a previous section: Cause-related marketing, corporate constructivism, maximizing the shareholder value and the common good approach. 


\section{Cause-related marketing.}

The cultural events, popular festivities and contests sponsored by tobacco companies may be understood as tools to improve image or to create a smoke screen just with an external makeover to divert criticism from NGOs. In this way "many corporations have taken up CSR less out of conviction and more to deflect criticism from NGOs, the commitment being more apparent than real" (Hirschhorn, 2004, p. 448) ${ }^{2}$. Likewise, even if they are not promoting directly cigarette consumption in these events, they are creating spaces to present a positive image of the company to smokers or potential smokers, building this image around the ideas of credibility and honesty. Also, recalling article 16 of the Colombian tobacco control act, "all forms of promotion of tobacco products and their derivatives are banned", this type of event sponsorship should not be advertised. According to Asma et al. (2009), many authors have reflected upon this issue:

In the area of advertising and promotion, the tobacco companies have developed target marketing campaigns including sponsorship of cultural and sports events, have worked to circumvent marketing restrictions when attempts to prevent or modify marketing restrictions had failed and have developed new products to continue to appeal to young people (Dewhirst \& Hunter, 2002; Pollay \& Dewhirst, 2002; Neuman et al., 2002; Wakefield et al., 2002; Assunta \& Chapman 2004; Barbeau et al., 2004; Smith \& Maone, 2006; Anderson et al. 2005; Carpenter et al., 2005; LeGresley et al., 2006; MacKenzie et al., 2007) (p. 1289).

On the other hand, smoking cessation or educational campaigns sponsored by the tobacco companies can be considered marketing strategies. Shafey, Eriksen, Ross and Mackay (2009) states that

[...] the tobacco industry seizes the opportunity to burnish its public image by funding youth smoking prevention programs. Unsurprisingly, most industry-sponsored youth programs employ measures known to have minimal impact on youth smoking uptake. In many cases, they encourage smoking by associating the behavior with aspirational ideals of maturity and freedom (smoking as an "adult choice") (p. 78).

\section{Corporate constitutionalism.}

During the news search it became evident that some institutions and regional entities recognize tobacco companies as a legitimate party to perform interventions related with development goals of the country. Tobacco companies frequently act in alliance with government agencies to establish crop expansion programmes and they even use the support of NGOs to develop their activities oriented to former members of illegal armed forces or natural disaster victims. Thus, their projects usually are concerned with social issues of great importance to the country. Some state that it is, in the words of a small town major, "....satisfactory that such companies come to our municipality because with them also arrives development and education for the most deprived young people" (Leyva, 16 de septiembre de 2010). It is worth noting that this political and social recognition has brought distinctions and awards to the tobacco companies granted by highly reputable institutions in Colombia.

However, in this analysis there are three aspects that should be taken into consideration. First, it is appropriate to remember the study of Fooks et al. (2011) about BAT incentives to perform CSR initiatives, with the purpose of restoring its legitimacy among political elites and manage its reputation. This study concludes that such activities are tools to secure access to key decision makers and influence their views.

In this respect, BAT's engagement with the DoH illustrates the way in which CSR offers companies with poor social or environmental 
records a structured environment of dialogue and engagement, which shifts attention away from both the social costs associated with the business and any past behavior that might cause doubts about the trustworthiness of the company and the relative merits of granting it access (Fooks et al., 2011, p. 8).

Otherwise, it is important to highlight that PMI makes explicit in its web page its advocacy interests (PMI, 2015a, 2015b).

Following the same path, in 1997, at the face of the legal suits against the tobacco companies in the United States, PMI consultants recommended the use of these type of strategies to "clean" the company's image and present itself as a good corporate citizen (Hirschhorn, 2004). In other words,

[...] several transnational tobacco companies have engaged in efforts to present themselves as socially responsible, demonstrating that these efforts are no more than public relations campaigns in response to increasing litigation against the industry, as well as increasing public perception of tobacco companies as untrustworthy (Asma et al., 2009, p.1289).

Second, the support provided by these companies to tobacco cultivation should be studied carefully in the future, because this activity is generating an increased dependence relationship between peasants and tobacco companies. Tobacco companies own the seeds provided to the small farmers and they become the sole buyers of the crops. Third, and considering the former idea, it is possible to infer that in the long run this type of strategies is not sustainable. In view of the iron law of responsibility, gradually more national and international organizations claim for greater accountability of tobacco companies. Examples of these are WHO, the World Heart Federation, the National Cancer Institute, the Colombian Cardiology Association, the Colombian League against Cancer, and Corporate Accountability.

\section{Maximizing the shareholder value}

Some organizations like WHO (Las tabacaleras buscan más fumadores en países pobres, 08 de febrero de 2008) have publicly denounced that tobacco companies' strategies aim at increasing cigarette consumption in non-developed countries, mainly among women and children. The report of Harvard's School of Public Health also illustrates this trend stating that "tobacco companies use a deliberate strategy to recruit and engage young smokers, adjusting menthol levels to create a milder initial experience for those who are just starting to smoke" (EFE, 16 de julio de 2008). From this perspective, these strategies could be understood as actions to increase sales and maximize shareholders' investment, and CSR initiatives, especially those related with youth campaigns' category, play the role of complementary elements to reach that objective and counteract negative image effects stemming from the consumption of their products.

\section{Common good approach}

The origin of the firms could be explained as the wish to supply with products the needs expressed by the people. However, in the case of tobacco this need is turned into a healthdamaging addiction that causes close to 6 million deaths every year in the world (World Health Organization - WHO, 2011). In fact, authors like Debeljuh (2009) explain why products such as tobacco are excluded from ethical investment funds. According to Debeljuh "the central criterion to select [firms by ethical funds] is the nature of the products or services offered by the firm ... [and] the possible effects of these products on the environment or on the health", $(2009$, p. 68) thus, investment in tobacco companies is not considered a responsible investment. Likewise, the review by Hirschhorn (2004) about firms selected in "social funds", none of these considered tobacco companies suitable, with the exception of the Dow Jones Sustainability Index, which includes BAT ${ }^{3}$. 
In this approach, the organizations have responsibility to contribute to common good (Melé, 2004) offering some conditions for social life. Having this in mind, it might be possible to consider whether tobacco companies contribute to the objective proposed in the approach. But the nature of the product, the evidence collected for this study and in the other analyses mentioned above, it becomes clearer that these companies cannot be labeled as CSR organizations. The dignity of the human being and their physical integrity should always be at the center of the debates, without forgetting that social and economic development in a country should be viewed as a tree-legged commitment, with private firms, civil society and government joining forces to reach wellbeing for all members of society. Thus, every one according to their role may contribute to the curbing of the tobacco epidemic.

\section{Conclusions and recommendations}

The first conclusion after performing this analysis is that tobacco companies in Colombia have devised several CSR strategies surrounding their expansion plans in the country, supported by the idea that they are key partners in the country's development efforts. Consequently, such programmes should be seen as tools to reach two objectives. The first one is improving the companies' image and counteracting the negative image impacts emerging from the damages caused by tobacco consumption. The second objective of this expansion projects, closely related to the former one, is gaining influence on political processes and facilitating access to decision makers. The frequent alliances with other organizations, mostly from the public sector, reinforce this idea. Recalling Fooks et al. (2011) this would not be the first time that tobacco companies use CSR as a mechanism to restore their legitimacy with the purpose of accessing to policymakers and having chances of influencing policy decisions related to tobacco regulation. This efforts would be aimed to soften that regulation.
Considering these, a first recommendation is to review the current mechanisms established in the country to secure compliance with FCTC commitments and dispositions in Law 1335 regarding bans to advertising, promotion and sponsorship. Additionally, it is necessary to pay attention to tobacco industry's advocacy because it could point at the gap in regulation to secure independence of public policy health objectives.

Other area that requires special attention is the breach created by the tobacco companies in the interpretation of the scope of the ban to sponsorship. The FCTC defines tobacco sponsorship as "any form of contribution to any event, activity or individual with the aim, effect or likely effect of promoting a tobacco product or tobacco use either directly or indirectly." (World Health Organization - WHO, 2003). Thus, the idea spread by some tobacco firm's representatives about the acceptability of their sponsorship activities constitutes a misleading interpretation of the ban, and this remains an area of violation of the dispositions both in the FCTC and in Law 1335. Therefore, it is relevant to argue that the CSR strategies of the tobacco industry should be classified as a promotion scheme, and consequently, that they should be restricted under the current ban to promotion in Colombia.

Another aspect that became evident throughout the analysis was the similarity of strategies used by tobacco companies in other countries. This is one of the reasons why mechanisms to secure a standard interpretation of the FCTC are so important. It is also important to increase efforts in terms of making these strategies visible and learn from the experience in other countries dealing with the attempts of tobacco companies to use CSR as a tool to by-pass sponsorship bans and to increase accessibility to political elites. It is also necessary to monitor regularly these activities to interpret their maneuvers and generate appropriate responses. Applying the following message to the presented arena, Asma et al. 
(2009, p.1289) say that "[...] only by knowing its history and conduct, monitoring its current behaviour, and regulating and restricting the environment in which the industry operates, can public health strategies be effective". In this case, the law compliance can be effective. From this perspective, it is important to actualize this study in future researches.

Moreover, considering the influence of transnational companies in the current global context, and particularly of tobacco companies, all agents must adopt an active role and demand greater accountability to reduce the danger of manipulations and law violations. It is not enough to have tobacco control legislation.

Finally, it was not possible to conclude in this study if there were any changes in the intensity of CSR before and after the passing of the tobacco control act in Colombia. However, the evidence shows that there is a strong and persistence emphasis on interventions in the rural areas and the agricultural sector. PMI and BAT had a company's strategy to increase crops to reach its export goals. Furthermore, their expansion plans are related with their CSR programmes. In addition, both companies (BAT and PMI) have concentrated their CSR on the same areas for the last five years. Only PMI has included recently a new one about advocacy interests.

\section{Notas}

${ }^{1}$ With an exchange rate average of $\$ 1967$ pesos per dollar in 2008.

${ }^{2}$ Henderson agrees that many corporations have taken up CSR less out of conviction and more to deflect criticism from NGOs, the commitment being more apparent than real

${ }^{3}$ Regarding these type of arguments PMI has identified itself as an ethical firm: "In 1996 its CEO Geoffrey Bible defended the company in an address to its employees: [...] We are right because for millions of people, smoking is part of an adult lifestyle... We are right because cigarettes are a legal product... What some people may not understand is that we are an ethical company. Our tobacco business may be controversial, but we are principled people who are honest and straight-dealing [...]" (Hirschhorn, 2004, p. 449).

\section{References}

Aguilar, I. (2011). Algunas consideraciones sobre la responsabilidad social empresarial. Revista Civilizar de Empresa y Economía, 2(4), 133-137.

Alianza de BAT Colombia con un techo para mi país. (03 de abril de 2010). EL Tiempo. Recuperado de http://www.eltiempo. com/archivo/documento/MAM-3905221

Ambientes laborales sanos. (24 de marzo de 2010). El Tiempo. Recuperado de http:// www.eltiempo.com/archivo/documento/ CMS-7471469

Argandoña, A. (2007a). La Responsabilidad Social de la empresa a la luz de la ética. IESE Business School (Documento de investigación No. 708). (Universidad de Navarra), Recuperado de http://www. iese.edu/research/pdfs/DI-0708.pdf

Argandoña, A. (2007b). Responsabilidad social de la empresa: ¿Qué modelo económico?. IESE Business School (Documento de investigación No.709). Recuperado de http://www.iese.edu/research/pdfs/DI0709.pdf

Argandoña, A. (2007c). Responsabilidad social y creación de valor para el accionista: ¿Objetivos contrapuestos o complementarios? IESE Occasional Paper, 3(7), 1-13. Recuperado de http://www.iese. edu/research/pdfs/op-07-16.pdf 
Aristóteles. (2013). Ética nicomaquea. En. A. Gómez, (Ed.). Gómez, Ed.). México: Editorial Porrúa.

Artuz. (24 de noviembre de 2011). A seis desmovilizados les cambió la vida gracias a nuevos minimercados. El Tiempo. Recuperado de http://m.eltiempo.com/colombia/ barranquilla/a-seis-desmovilizados-lescambi-la-vida-gracias-a-nuevos-minimercados/10820164

Asma, S., Bettcher, D. W., Samet, J., Palipudi, K. M., Giovino, G., Bialous, S., \& Yach, D. (2009). Tobacco (Vol. 3). En R. Detels, R. Beaglehole, M. A. Lansang, \& M. Gulliford (Eds.), Oxford Textbook of Public Health (Fifth edit.). Oxford University Press. doi:10.1093/ med/9780199218707.003.0075

Atusingwize, E., Lewis, S., \& Langley, T. (2015). Economic evaluations of tobacco control mass media campaigns: a systematic review. Tobacco Control, 24(4), 320-327. doi:10.1136/tobaccocontrol-2014-051579

British American Tobacco-[BAT]. Seguirá con salón de arte popular; Ley antitabaco no afectará su realización. (26 de julio de 2009). El Tiempo. Recuperado de http:// www.eltiempo.com/archivo/documento/CMS-5704949

British American Tobacco-[BAT]. (2010). Responsables por convicción. Recuperado de http://www.batcolombia.com/group/sites/BAT_87AF9V.nsf/vwPagesWebLive/ DO87XḦHJ?opendocument\&SKN=1

British American Tabacco-[BAT]. Compra a Protabaco por US\$452 millones. (26 de mayo de 2011). El Tiempo. Recuperado de http:// www.eltiempo.com/economia/empresas/ ARTICULO-WEB-NEW_NOTA_INTERIOR-9455604.html
British American Tobacco-[BAT]. (2011). Responsables por convicción. Recuperado de http://www.batcolombia.com/group/ sites/BAT_87AF9V.nsf/vwPagesWebLive/DO87XHHJ?opendocument\&SKN=1

British American Tobacco-[BAT]. (2011). El III Salón BAT de arte popular - Bicentenario de la Independencia premió a 7 artistas empíricos. Recuperado de http:// www.fundacionbat.com.co./noticia. php?idnot $=728$

British American Tobacco [BAT]. (2015). Bienvenido a British American Tobacco Colombia. Recuperado de http://www. batcolombia.com/

Cabalgata, concierto, toros y silletas son las actividades programadas para la fiesta de Sogamoso. (15 de julio de 2010). El Tiempo. Recuperado de http://www.eltiempo.com/ archivo/documento/CMS-7809233

Campaña contra el cigarrillo para menores de edad. (20 de octubre de 2008). El Tiempo. Recuperado de http://www.eltiempo. com/archivo/documento/MAM-3146628

Carroll, A. (1999). Corporate Social Responsibility: Evolution of a Definitional Construct. Business \& Society, 38(3), 268-295. doi:10.1177/000765039903800303

Catecismo Iglesia católica [CIC]. (1992). Catecismo de la Iglesia católica. Madrid: Asociación de Editores Catecismo.

Chapman, S. (2004). Advocacy in action: extreme corporate makeover interruptus: denormalising tobacco industry corporate schmoozing. Tobacco Control, 13(4), 445-447. doi:10.1136/tc.2004.010025

Cigarrillos con sello propio. (21 de junio de 2011). EL Espectador. Recuperado de 
http://www.elespectador.com/impreso/ negocios/articulo-279061

Cisterna-Cabrera, F. (2005). Categorización y triangulación como procesos de validación del conocimiento en investigación cualitativa. Theoria, 14(1), 61-71.

Citytv. (29 de mayo de 2009). Proyecto de Ley que pretende regular el consumo de tabaco crea polémica. Recuperado de http://www.citytv.com.co/videos/9918

Coltabaco busca el mejor talento de las universidades en Colombia. (23 de noviembre de 2010). Revista Dinero. Recuperado de http://www.dinero.com/ actualidad/noticias/articulo/coltabacobusca-mejor-talento-universidades-colombia/108090

Coltabaco exportará, por primera vez, sus productos a Brasil. (10 de febrero de 2009). El Espectador. Recuperado de http:// www.elespectador.com/noticias/negocios/articulo116789

Coltabaco impulsa el cultivo de 500 hectáreas de tabaco en la costa norte. (03 de diciembre de 2008). El Espectador. Recuperado de http:// www.elespectador.com/articulo95867

Comprometida con la prevención del consumo de tabaco en menores de edad. (30 de agosto de 2008). El Tiempo. Recuperado de http://www.eltiempo.com/archivo/ documento/MAM-3073790

Con "Micos" en Ley antitabaquismo buscan eliminar espacios libres de humo. (21 de mayo de 2009). El Tiempo. Recuperado de http://www.eltiempo.com/archivo/ documento/CMS-5246887

Contratos para fomentar cultivo de tabaco. (21 de abril de 2009). El Tiempo. Recuperado de http://www.eltiempo.com/archivo/ documento/MAM-3408466

Cultivos de tabaco generarán más empleos en el Quindío. (19 de marzo de 2010). El Tiempo. Recuperado de http://www.eltiempo.com/ archivo/documento/CMS-7414947

Davis, K. (1960). Can Business Afford to Ignore Corporate Social Responsibilities? California Management Review, 2, 70-76.

Dawkins, J. (2005). Corporate responsibility: The communication challenge. Journal of Communication Management, 9(2), 108119. doi:10.1108/13632540510621362

De Espejo, G. (07 de noviembre de 2008). Amenazas por ley antitabaco. El Espectador. Recuperado de http://www.elespectador. com/impreso/articuloimpreso88989-amenazas-ley-antitabaco

Debeljuh, P. (2009). Ética Empresarial en el núcleo de la estrategia corporativa. Buenos Aires: Cengage Learning.

Dmoteroa. (22 de mayo de 2009). Avanza proyecto que tumbaría prohibición de fumar en espacios públicos. Caracol. Recuperado de http://www.noticiascaracol.com/ politica/articulo139920-avanza-proyecto-tumbaria-prohibicion-de-fumar-espacios-publicos

EFE. (19 de mayo de 2008). Una Restrictiva Ley Antitabaco entra en Vigor en Turquía. El Espectador. Recuperado de http:// www.elespectador.com/noticias/salud/ articulo-una-restrictiva-ley-antitabacoentra-vigor-turquia

EFE. (16 de julio de 2008). Acusan a Tabacaleras de Manipular Mentol en Cigarrillos. El Espectador. Recuperado de http:// www.elespectador.com/noticias/salud/ar- 
ticulo-acusan-tabacaleras-de-manipularmentol-cigarrillos

El país sembrará más tabaco. (19 de septiembre de 2009). El Tiempo. Recuperado de http://www.eltiempo.com/archivo/documento/MAM-3632777

En el Congreso de la Republica tres proyectos de ley sobre el tema. (27 de mayo de 2008). El Tiempo. Recuperado de http:// www.eltiempo.com/archivo/documento/ CMS-4210671

En pro del arte. (22 de abril de 2008) El Tiempo. Recuperado de http://www.eltiempo. com/archivo/documento/MAM-2907395

En sus marcas. (16 de noviembre de 2011). El Tiempo. Recuperado de http://www. eltiempo.com/archivo/documento/CMS10776947

Fooks, G. J., Gilmore, A. B., Smith, K. E., Collin, J., Holden, C., \& Lee, K. (2011). Corporate social responsibility and access to policy élites: an analysis of tobacco industry documents. PLoS Medicine, 8(8), doi:10.1371/journal.pmed.1001076

Friedman, M. (september $13^{\text {th }}$, de1970). The social responsibility of Business is to increase its profits. The New York Times Magazine. Recuperado de http://www. colorado.edu/studentgroups/libertarians/ issues/friedman-soc-resp-business.html

Garriga, E., \& Melé, D. (2004). Corporate Social Responsibility Theories: Mapping the Territory. Journal of Business Ethics, 53(1/2), 51-71. doi:10.1023/ B:BUSI.0000039399.90587.34

Garriga, E., \& Melé, D. (2013). Corporate Social Responsibility Theories: Mapping the Territory. En A. C. Michalos \& D. C.
Poff (Eds.), Citation Classics from the Journal of Business Ethics, 4(2), 69-96. doi:10.1007/978-94-007-4126-3_4

Grougiou, V., Dedoulis, E., \& Leventis, S. (2015). Corporate Social Responsibility Reporting and Organizational Stigma: The Case of "Sin" Industries. Journal of Business Research. (En prensa). doi:10.1016/j.jbusres.2015.06.041

Hay micos de senadores en ratificación del convenio contra el tabaco Claudia Víctor. (12 de abril de 2009). El Tiempo. Recuperado de http://www.eltiempo. com/archivo/documento/MAM-3395499

Hernández, D. (13 de abril de 2011). Primera jornada recolección de colillas de cigarrillo. CityTv. Recuperado de http://www.citytv. com.co/videos/408238/primera-jornadarecoleccion-de-colillas-de-cigarrillo

Hirschhorn, N. (2004). Corporate social responsibility and the tobacco industry: hope or hype? Tob Control, 13, 447-453.

Ho, M. G., Shi, Y., Ma, S., \& Novotny, T. E. (2007). Perceptions of tobacco advertising and marketing that might lead to smoking initiation among Chinese high school girls. Tobacco Control, 16(5), 359-60. doi:10.1136/tc.2007.022061

Hoyos-Vásquez, G., \& Solarte, R. (2007). Modelo y metodología para la gestión en RSE. Bogotá: BID-Confecámaras.

La nueva cara de El Salado. (08 de julio de 2011). El Espectador. Recuperado de http://www.elespectador.com/impreso/ negocios/articulo-282748

Las tabacaleras buscan más fumadores en países pobres. (08 de febrero de 2008). El Tiempo. Recuperado de http://www.eltiempo.com/archivo/documento/MAM2820154 
Ley antitabaco supera otro escollo en el senado. (19 de noviembre de 2008). El Espectador. Recuperado de http://www. elespectador.com/noticias/politica/articulo91709

Ley 1335 de 2009. Disposiciones por medio de las cuales se previenen daños a la salud de los menores de edad, la población no fumadora y se estipulan políticas públicas para la prevención del consumo del tabaco y el abandono de la dependencia del tabaco del fumador y sus derivados en la población colombiana. Diario Oficial 47.417. Congreso de la República de Colombia, julio de 2009.

Leyes confinan a fumadores en sus casas. (03 de enero de 2008). El Tiempo. Recuperado de http://www.eltiempo.com/archivo/ documento/MAM-2783414

Leyva, L. (16 de septiembre de 2010). Coltabaco inauguró agencia de compra de tabaco rubio en El Carmen. El Universal. Recuperado de http://www.eluniversal. com.co/cartagena/bolivar/coltabacoinauguro-agencia-de-compra-de-tabacorubio-en-el-carmen

Lindgreen, A., Córdoba, J. R., Maon, F., \& Mendoza, J. M. (2010). Corporate social responsibility in Colombia: Making sense of social strategies. Journal of Business Ethics, 91, 229-242. doi:10.1007/s10551010-0616-9

Lin-Hi, N., \& Müller, K. (2013). The CSR bottom line: Preventing corporate social irresponsibility. Journal of Business Research, 66(10), 1928-1936. doi:10.1016/j. jbusres.2013.02.015

Mantienen oferta de crédito. (29 de mayo de 2010). El Tiempo. Recuperado de http:// www.eltiempo.com/archivo/documento/ MAM-3988041
Mira, N. (31 de diciembre de 2011). Víctimas $\mathrm{y}$ victimarios se encuentran en ruta ciudadana, en Medellín. El Tiempo. Recuperado de http://www.eltiempo.com/ colombia/medellin/ARTICULO-WEBNEW_NOTA_INTERIOR-10930946. html

Melé, D. (2004). La relación empresa-sociedad como base para la responsabilidad de la empresa en la sociedad. En M. Paladino (Ed.), La responsabilidad de la empresa en la sociedad (pp. 153-170). Buenos Aires: Ariel Sociedad Económica.

Niño-Muñoz, D. (2012). La responsabilidad social corporativa, una construcción entre todos. En L. Irizar (Ed.), Humanización de la vida sociopolítica según Caritas in veritate (pp. 199-210). Bogotá: Editorial San Pablo.

No fue aprobada la compra de Protabaco por Phillip Morris. (13 de junio de 2010). El Tiempo. Recuperado de http://www. eltiempo.com/archivo/documento/ MAM-4008137

Paladino, M., \& Willi, A. (2004). La dimensión política del directivo de empresa. En: M. Paladino (Ed.), La responsabilidad de la empresa en la sociedad (pp. 91-121). Buenos Aires: Ariel Sociedad Económica.

Palazzo, G., \& Richter, U. (2005). CSR business as usual? The case of the tobacco industry. Journal of Business Ethics, 61(4), 387-401.

Park, J., Lee, H., \& Kim, C. (2014). Corporate social responsibilities, consumer trust and corporate reputation: South Korean consumers' perspectives. Journal of Business Research, 67(3), 295-302. doi:10.1016/j.jbusres.2013.05.016

Patino, C. (2013). Coltabaco, una empresa de Philip Morris International, Inc. Recupe- 
rado de https://prezi.com/ji4nnxmydfjh/ comunicaciones/\#

Pezoa, A. (2004). ¿Hacer o parecer? En: M. Paladino (Ed.), La responsabilidad de la empresa en la sociedad (pp. 273286). Buenos Aires: Ariel Sociedad Económica.

Philip Morris compra a Protabaco por US $\$ 452$ millones. (10 de julio de 2009). El Espectador. Recuperado de http://www.elespectador.com/economia/articulo149947

Philip Morris International- [PMI]. (2015a). Government advocacy. Recuperado de http://www.pmi.com/eng/about_us/government_advocacy/pages/government_ advocacy.aspx

Philip Morris International- [PMI]. (2015b). Prevención del consumo de tabaco por los menores. Recuperado de http://www. pmi.com/esp/about_us/how_we_operate/ pages/youth_smoking_prevention.aspx

Phillip Morris niega sobornos para tumbar Ley Antitabaco. (12 de junio de 2009). El Espectador. Recuperado de http:// www.elespectador.com/noticias/politica/ articulo145666

Piden revocar medidas contra los fumadores. (05 de julio de 2008). El Tiempo. Recuperado de http://www.eltiempo.com/archivo/ documento/MAM-3002024.

Piden erradicar miedo de contratar desmovilizados. (05 de mayo de 2011). El Tiempo. Recuperado de http://www.eltiempo.com/archivo/documento/MAM4537574

Polémica por venta fácil de cigarrillos. (05 de mayo de 2009). El Espectador. Recuperado de http://www.elespectador. com/noticias/salud/articulo139368
Porter, M. E., \& Kramer, M. R. (2006). Strategy and society: The link between competitive advantage and corporate social responsibility. Harvard Business Review, 84, 78-92. doi:10.1287/mnsc.1090.1070

Premiaron a 58 empresas bogotanas por ser amigables con medio ambiente. (22 de diciembre de 2010). El Espectador. Recuperado de http://www.elespectador. com/noticias/bogota/articulo-241779

Prohíben fumar en recintos públicos. (31 de mayo de 2008). El Tiempo. Recuperado de http://www.eltiempo.com/archivo/documento/MAM-2957571

Protabaco alista plan para mejorar cultivos. (19 de mayo de 2008). El Tiempo. Recuperado de http://www.eltiempo.com/archivo/ documento/MAM-2941264

Protabaco firma nuevos contratos de exportación. (11 de marzo de 2008). El Tiempo. Recuperado de http://www.eltiempo. com/archivo/documento/MAM-2858524

Protabaco (2011). Protabaco Home page. Recuperado de http://www.protabaco. $\mathrm{com} /$ scripts/responsabilidad_social.php? $\mathrm{MP}=24 \& \mathrm{IdCont}=31$

Quintero, F. (08 de junio de 2010). Tabacaleros harían bloqueos. El Tiempo. Recuperado de http://www.eltiempo.com/archivo/ documento/MAM-4000504

Rodríguez, C. (15 de junio de 2009). ¿Humo negro del cigarrillo en el Congreso? El Espectador. Recuperado de http://www. elespectador.com/columna145981-humonegro-del-cigarrillo-el-congreso

Santos dice que en la masacre de El Salado hubo omisión. (08 de julio de 2011). El Tiempo. Recuperado de http://www.eltiempo.com/ archivo/documento/CMS-9850765 
Shafey, O., Eriksen, M., Ross, H., \& Mackay, J. (2009). The tobacco atlas (Ed.3). Atlanta: American Cancer Society.

Tabaquismo en niños, lío mayor. (23 de julio de 2008). El Tiempo. Recuperado de http:// www.eltiempo.com/archivo/documento/ MAM-3025306

Ulin, P. R., Robinson, E. T., \& Tolley, E. E. (2006). Investigación aplicada en salud pública Métodos cualitativos. Washington, DC: Organización Panamericana de la Salud. Recuperado de http:// iris.paho.org/xmlui/bitstream/handle/ 123456789/729/9275316147.pdf

World Health Organization-[WHO]. (2003) Framework Convention on Tobacco
Control (FCTC). Recuperado de http:// www.who.int/tobacco/framework/ WHO_FCTC_english.pdf

World Health Organization -[WHO]. (2011). Global status report on noncommunicable diseases. World Health Organitation Press. Recuperado de http://apps.who. int/medicinedocs/documents/s18629en/ s18629en.pdf

Yoon, Y., Gürhan-Canli, Z., \& Schwarz, N. (2006). The effect of corporate social responsibility (csr) activities on companies with bad reputations. Journal of Consumer Psychology, 16(4), 377390. doi:10.1207/s15327663jcp1604_9 
Annex 1. CSR initiatives of tobacco companies in Colombia

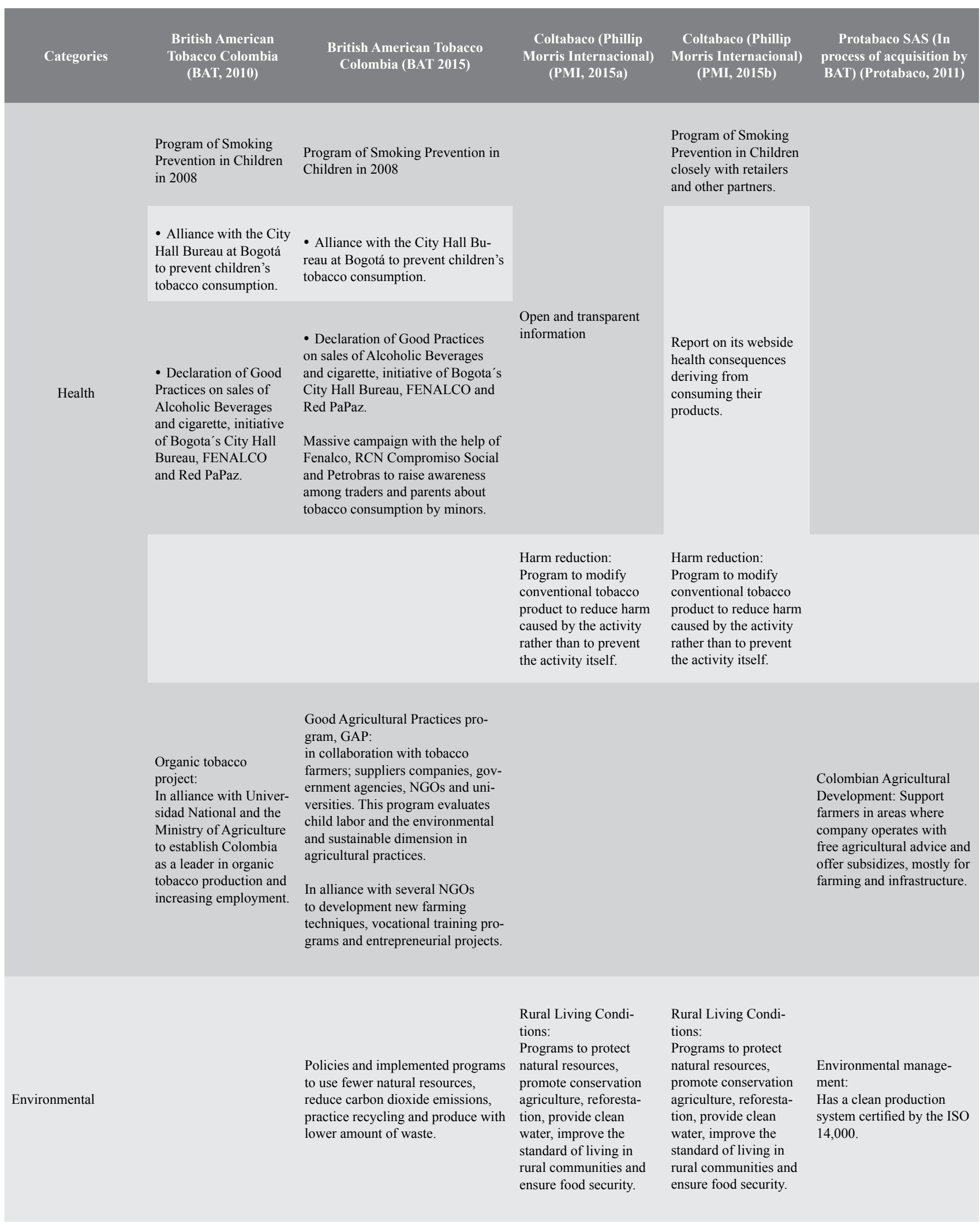




\begin{tabular}{|c|c|c|c|c|c|}
\hline Categories & $\begin{array}{l}\text { British American } \\
\text { Tobacco Colombia } \\
\text { (BAT, 2010) }\end{array}$ & $\begin{array}{l}\text { British American Tobacco } \\
\text { Colombia (BAT 2015) }\end{array}$ & $\begin{array}{l}\text { Coltabaco (Phillip } \\
\text { Morris Internacional) } \\
\text { (PMI, 2015a) }\end{array}$ & $\begin{array}{l}\text { Coltabaco (Phillip } \\
\text { Morris Internacional) } \\
\text { (PMI, 2015b) }\end{array}$ & $\begin{array}{l}\text { Protabaco SAS (In } \\
\text { process of acquisition by } \\
\text { BAT) (Protabaco, 2011) }\end{array}$ \\
\hline \multirow{4}{*}{ Social } & $\begin{array}{l}\text { Volunteer Program } \\
-2010 \\
\text { Alliance with founda- } \\
\text { tion "Un techo para } \\
\text { mi país" to help in } \\
\text { provisional housing } \\
\text { solutions. }\end{array}$ & $\begin{array}{l}\text { Supported in NGOs to improve lo- } \\
\text { cal communities through donations } \\
\text { and volunteer activities. }\end{array}$ & $\begin{array}{l}\text { Education } \\
\text { Program to renovate } \\
\text { rural public schools and } \\
\text { to improve teaching } \\
\text { curriculum for children } \\
\text { in rural communities in } \\
\text { alliance with the Minis- } \\
\text { try of Education. }\end{array}$ & $\begin{array}{l}\text { Education } \\
\text { Global program to } \\
\text { offer education for } \\
\text { children in tobacco } \\
\text { areas and for teachers. } \\
\text { Financial support to } \\
\text { teachers, community } \\
\text { groups and other } \\
\text { specialists to prevent } \\
\text { tobacco consumption } \\
\text { by minors }\end{array}$ & \multirow[t]{2}{*}{$\begin{array}{l}\text { Employment } \\
\text { Job Generation for } \\
\text { displaced people by } \\
\text { violence, illicit production } \\
\text { or under extreme poverty } \\
\text { conditions. }\end{array}$} \\
\hline & $\begin{array}{l}\text { British American } \\
\text { Tobacco Colombia } \\
\text { Foundation } \\
\text { Created in } 2000 \text { this } \\
\text { foundation intends } \\
\text { to support cultural } \\
\text { activities in Colombia, } \\
\text { like popular festivals, } \\
\text { national artists exhibi- } \\
\text { tion, etc. }\end{array}$ & $\begin{array}{l}\text { British American Tobacco Colom- } \\
\text { bia Foundation } \\
\text { Created in } 2000 \text { this foundation } \\
\text { intends to support cultural activities } \\
\text { in Colombia, like popular festivals, } \\
\text { national artists exhibition, etc. }\end{array}$ & $\begin{array}{l}\text { Hunger and Extreme } \\
\text { Poverty } \\
\text { Global Programs to pro- } \\
\text { vide direct relief to poor } \\
\text { and hungry people. }\end{array}$ & $\begin{array}{l}\text { Hunger and Extreme } \\
\text { Poverty } \\
\text { Global Programs to } \\
\text { provide direct relief } \\
\text { to poor and hungry } \\
\text { people. }\end{array}$ & \\
\hline & & & $\begin{array}{l}\text { Disaster Relief } \\
\text { Programs to help and } \\
\text { identify essential needs } \\
\text { of the community where } \\
\text { disasters occur. }\end{array}$ & $\begin{array}{l}\text { Disaster Relief } \\
\text { Programs to help and } \\
\text { identify essential needs } \\
\text { of the community } \\
\text { where disasters occur. }\end{array}$ & \\
\hline & & & $\begin{array}{l}\text { Domestic Violence } \\
\text { Support refugees, child } \\
\text { protection across the } \\
\text { country, emergency } \\
\text { financial assistance and } \\
\text { legal services. }\end{array}$ & $\begin{array}{l}\text { Domestic Violence: } \\
\text { Support refugees, child } \\
\text { protection across the } \\
\text { country, emergency } \\
\text { financial assistance } \\
\text { and legal services. } \\
\text { Training for women } \\
\text { in alliance with other } \\
\text { companies and govern- } \\
\text { ment organizations }\end{array}$ & \\
\hline & & & & $\begin{array}{l}\text { "Advocacy to esta- } \\
\text { blish regulations ... } \\
\text { to prevent tobacco } \\
\text { consumption by mi- } \\
\text { nors" (PMI, 2015a) }\end{array}$ & \\
\hline Regulation & & & & $\begin{array}{l}\text { Clarify PMI's views } \\
\text { "to those who } \\
\text { have the potential } \\
\text { to affect the laws, } \\
\text { regulations, and } \\
\text { policies that can } \\
\text { influence [its] glo- } \\
\text { bal business" (PMI, } \\
\text { 2015b) }\end{array}$ & \\
\hline
\end{tabular}

Note: This table summarizes, according to categories established by the author, the CSR programmes stated by BAT and PMI in their local and international web pages respectively. 